Man and Nature

MAN AND NATURE

L'homme et la nature

L'HOMME ET LA NATURE

\title{
'So proper for that constant pocket use': Posthumous Editions of Pope's Works (1751-1754)
}

\section{Donald W. Nichol}

Volume 6, 1987

URI : https://id.erudit.org/iderudit/1011872ar

DOI : https://doi.org/10.7202/1011872ar

Aller au sommaire du numéro

Éditeur(s)

Canadian Society for Eighteenth-Century Studies / Société canadienne d'étude du dix-huitième siècle

ISSN

0824-3298 (imprimé)

1927-8810 (numérique)

Découvrir la revue

Citer cet article

Nichol, D. W. (1987). 'So proper for that constant pocket use': Posthumous

Editions of Pope's Works (1751-1754). Man and Nature / L'homme et la nature, 6,

81-92. https://doi.org/10.7202/1011872ar

Copyright (c) Canadian Society for Eighteenth-Century Studies / Sociéte canadienne d'étude du dix-huitième siècle, 1987
Ce document est protégé par la loi sur le droit d'auteur. L'utilisation des services d'Érudit (y compris la reproduction) est assujettie à sa politique d'utilisation que vous pouvez consulter en ligne.

https://apropos.erudit.org/fr/usagers/politique-dutilisation/ 


\section{'SO PROPER FOR THAT CONSTANT POCKET USE': POSTHUMOUS EDITIONS OF POPE'S WORKS (1751-1754)}

What becomes of a poet's works after death has long been a lifetime preoccupation of the flourishing poet. Auden in commemorating Yeats noted that 'the death of the poet was kept from his poems', yet in 'Under Ben Bulben' Yeats hovers over his own burial composing his grim epitaph. Swift, another self-epitapher, tried to circumvent the problem of posthumous authorial absence by anticipating, in the 'Verses' on his own death, what the demand would be like for his life's writings:

Where's now this favourite of Apollo?

Departed; and his works must follow:

Must undergo the common fate;

His kind of wit is out of date.

Some country squire to Lintot goes,

Enquires for Swift in verse and prose:

Says Lintot, 'I have heard the name:

He died a year ago.' The same. ${ }^{1}$

Then, ignominy of ignominies, Lintot admits he has sent Swift's precious pages off to the 'pastry-cook's for wrapping material. ${ }^{2}$ Swift's wistfully self-ironic glimpse into posterity's estimation of his Works finds 
nothing to compare in Pope's more deliberate manoeuvres to ensure his own posthumous success. To this end, Pope engaged the services of William Warburton during the last five years of his life to collaborate on 'the Great Edition of my things with your Notes'. ${ }^{3}$ Their association as poet and editor is unique in literary history; never before had a poet made his living from the sale of books; never before had an editor inherited a literary estate of financial consequence. Pope's bequest was to make Warburton a wealthy, if embattled, man.

In the latter half of the eighteenth century, the copyright to Pope's Works was worth more to booksellers than the combined copyrights to the works of Milton and Shakespeare. ${ }^{4}$ Seven years after Pope's death a small group of booksellers headed by John and Paul Knapton published the Warburton edition of Pope's Works. The conditions of this somewhat troubled gestation period and its progeny need to be more fully examined. Pope's legacy to the man who came to his defence during the Essay on Man controversy proved to be a mixed blessing: while Warburton reaped considerable financial reward as a result of his association with Pope, he automatically became the prime victim of pamphlet attacks after Pope's decease. 'Together with his Works,' Warburton bitterly acknowledged in his preface to Pope's Works, 'he hath bequeathed me his DUNCES'. ${ }^{5}$ Between the time of the poet's death on 30 May and the publication of the first posthumous edition of his Works in June 1751, Warburton became embroiled in literary controversies which took their toll on the Pope edition. Various recent sources help identify who obtained Warburton's edition of Pope; and the surviving production records of the first five Warburton editions clearly indicate the extent of Pope's popularity in the decade after his death. ${ }^{6}$

In 1751 there were few signs which augured well for the public reception of Warburton's edition of Pope's Works. Publications attacking Warburton far outnumbered those sympathetic towards him, especially in the wake of the satirical reaction against Warburton's Shakespeare edition in 1747, followed by the Patriot King controversy of 1749 . The latter problem, stirred up by Lord Bolingbroke and his editor David Mallet in the 'Advertisement' to The Idea of a Patriot King, struck deeply at Pope's integrity, leaving Warburton in an awkward defensive position. Joseph Spence offered An Apology for the late Mr. Pope while Warburton anonymously released the rambling Letter to the Editor of the Letters on the Spirit of Patriotism, Ec. This was counterattacked by a pamphlet, To the Author of a Libel, entitled, A Letter to the Editor, Ec. which ranks high in the halitosis school of literary criticism: 'Like those who have a fetid breath, you are known in the dark'. It continues to question 
Whether you [i.e. Warburton] are a wrangling Wapping Attorney, a pedantic pretender to Criticism, an impudent paradoxical Priest, or an Animal yet stranger, an heterogenous Medley of all three (as your farraginous Stile seems to confess) there are few, I believe, would trouble themselves to determine, had you confined your insolence to your own stercoracious Rank. ${ }^{7}$

But, by far the most vicious attack against Warburton on this pamphlet battlefield was launched in A Familiar Epistle to the Most Impudent Man Living which, apart from unkindly referring to Warburton's wife and her uncle Ralph Allen, condemns the Warburton edition of Pope's Works two years before its release:

You signalized yourself by affecting to be the Bully of Mr. P.'s Memory, into whose acquaintance, at the latter End of the poor Man's life, you was $[s i c]$ introduced by your nauseous Flattery; and whose admirable Writings you are about to publish, with Commentaries worthy of Scriblerus himself; for we may judge of them beforehand, by the Specimens we have already seen of your Skill in Criticism. ${ }^{8}$

As an editor of Shakespeare, Warburton shared much the same fate as Pope did twenty-two years before. Reviving the spirit of Lewis Theobald (whose Shakespeare Restored prompted Pope to write The Dunciad), Thomas Edwards, John Upton, and Theophilus Cibber all sharply criticized Warburton's Shakespearean emendations and textual incrustations. ${ }^{9}$ In terms of sales, Warburton's Shakespeare edition fared poorly: listed originally at $£ 28 \mathrm{~s}$. in 1747 , it was being sold off at 18 shillings within a year. ${ }^{10}$ Without the purgative poetics of a Dunciad revisited, Warburton could do little more than save his venom for the footnotes of the Pope edition.

In the midst of Warburton's controversies -- the twin tempests of Shakespeare and Patriot King -- an unexpected hand administered a salve on Warburton's reputation thereby giving his Pope edition a badly needed boost. Tom Jones, a meatier kind of essay on man, was well peppered with references to Pope. Fielding's novel paid tribute to Pope's editor in the invocation to Book XIII at a time when Warburton would have been most wanting of a friendly word in print. The ten thousand sets of Tom Jones sold in 1749 alone must have helped clear away bad public opinion, especially when Fielding (without any apparent irony) asked the spirit of Learning, 'give me a-while that key to all thy treasures, which to thy Warburton thou hast entrusted.' 11 Warburton repaid the compliment in the footnotes to his Pope edition. ${ }^{12}$ 1751 -- the last full year of the Julian calendar -- is a significant land- 
mark in literary and book-trade history. Hume's Enquiry Concerning the Principles of Morals and Gray's Elegy Written in a Country Churchyard first saw print. For fiction-lovers, Fielding's last novel, Amelia, and Smollett's second, Peregrine Pickle, made their way on to the book lists. Across the channel, Voltaire's Age of Louis XIV was published; and the first volume of the Encyclopédie edited by Diderot and d'Alembert finally appeared, soon to be attacked by the same Jesuit organ, Mémoires de Trévoux, which had previously condemned Pope's Essay on Man. And, for our purposes, 1751 represents the culmination of Pope's and Warburton's association. For all modern editors of Pope's works, 1751 marks the beginning of many a bibliographical problem. As if to quash all future opposition, Warburton footnotes his authority on the first page of the 1751 preface: the relevant clause in Pope's will. ${ }^{13}$

Not even Warbuton knew exactly when his edition of Pope's Works would appear. To Thomas Balguy he wrote a week before the expected release date, 'Mr. Pope's Works ... will be published on the 1st., 2nd. or 3rd. of June'. ${ }^{14}$ Two weeks later, Horace Walpole was still waiting to see what Warburton would make of 'the famous piece of prose on Lord Hervey, which he formerly suppressed at my uncle's desire'. He conveyed to Montagu his grapevine gleanings: 'I am told the edition has waited, because Warburton has cancelled above a hundred sheets, (in which he had inserted notes) since the publication of the Canons of Criticism' ${ }^{15}$ Given Warburton's stern editorial temperament and the fact that the Pope edition comprised less than two hundred sheets, Walpole's figure is undoubtedly exaggerated. Still, we have some evidence of late or last-minute changes, the cancelled note on Mallet on the opening page of 'Arbuthnot' and the relocation of plate XVII between printing and binding being prime examples. ${ }^{16}$

The publication was announced in the June issue of London Magazine under 'Entertainment and Poetry': 'The Works of Alexander Pope, Esq; compleat in 9 Vols. 8vo. pr. $2 f$. 2s. in Sheets. Knapton.' There the potential buyer had every necessary detail: author and title; number of volumes and format; price and publisher. Two guineas would have been a substantial layout for one set of books, although when compared with the cost in 1755 of Dr. Johnson's two-volume Dictionary at $£ 4.10$ s., it was not so staggering a sum. Those too frugal to spend two guineas on their posthumous Pope could save about a third of the cost by waiting until autumn for the small octavo edition priced at twenty-seven shillings.

The publishing of Pope's Works was undertaken by a small group of booksellers - John and Paul Knapton, Henry Lintot, Jacob and Richard Tonson and Somerset Draper - most of whom had been familiar 
to Pope. John Knapton had supped with the poet at Twickenham. An older Bernard Lintot and Jacob Tonson had been lampooned in The Dunciad: three of the 1751 booksellers were heirs of the men who had published Pope from his earliest days. And the 1751 edition was printed by William Bowyer II, son of the original printer of Pope's 1717 Works. A tribute to book-trade continuity, the Warburton edition embodied some of the finest talents in the eighteenth-century publishing world. Between 1751 and 1755 some 10,750 sets - representing almost 100,000 single volumes - of Pope's Works were published in various formats.

A contemporary buyer had any number of reasons to purchase this item. Love of poetry and admiration for its finest contemporary proponent must figure as a prominent, if ideal, motive. Bibliophilic desire to have a complete, comprehensive and uniform set would have been another reason to buy it - Pope had altered his oeuvre with unsatisfying results, tinkering with format, fiddling with the arrangement of poems, keeping his editor at arm's length and switching printers between volumes after 1735. Many people would have bought this edition out of curiosity, knowing Warburton would be maligning some of the critics of his Shakespeare edition in the footnotes to Pope's Works. Some acquired this set because Pope was still de rigueur in polite circles (Elizabeth Carter, the celebrated bluestocking, quoted Pope frequently in her correspondence). Some would have purchased this handsome set to ornament their shelves and little more. A fairly substantial list of contemporary owners of the Warburton edition can now be compiled from various sources - library catalogues, auction records, book plates, private correspondence and common sense. Some sets, like the small 1751 octavo owned by Adam Smith, survive, ${ }^{17}$ while others, like the set owned by William Murray (which went up in flames along with the rest of his library during the mob violence of June 1780), do not. ${ }^{18}$

Most likely the first to receive their sets would have been Warburton's friends and assistants. The editor sent a list of names for complimentary sets to John Knapton on 3 June 1751. This list has not survived, although, in the letter it was attached to, Warburton somewhat testily questions whether George Arbuthnot, one of Pope's main executors, should have been included. ${ }^{19}$ Heading Warburton's list would have been Ralph Allen (his Prior Park benefactor and surrogate father-in-law), William Murray (Pope's old friend and Warburton's legal counsel) and the two proofreaders, John Jortin and Thomas Birch. ${ }^{20}$ Warburton's religious connections would not have been overlooked: just over a fortnight later, Warburton wrote Knapton, 'I have forgot to have a Book sent in Bords to the Bishop of Lincoln' ${ }^{21}$ William Mas- 
on, who had asked Warburton if writing poetry might interfere with his intended religious vocation, received a set of the 1751 edition; Charles Yorke would have been another likely recipient.

Warburton's protégé and eventual editor, Richard Hurd, received complimentary sets of both the 1751 and 1753 editions, the latter of which has been preserved in the Hartlebury Castle collection. Soon after forwarding the crown octavo set, Warburton wrote Hurd:

It may be just worth your while to tell you, before I conclude, that the small edition of Pope which I sent you, is the correctest of all; and I was willing you should always see the best of me.22

By this time Warburton had taken into account the recent publication of Hurd's Horatian translations - dedicated to Warburton. Hurd eagerly acknowledged Warburton's gift in a letter dated 2 July 1753:

Though my curiosity had not suffered me to neglect comparing the second edition of Pope in 8vo. with the first, which you gave me. And I had transcribed into it the most material corrections and alterations. But this smaller set is most acceptable to me, both for its being a proof of your kind remembrance of me; and also for the neatness and convenient size of the volume, so proper for that constant pocket use, which such a poet improved by such a critic deserves. ${ }^{23}$

Warburton may have wondered at the fulsome flattery and the unseemly puff, 'so proper for that constant pocket use', but then, he had been in much the same slavering posture with Pope ten years before.

After the complimentary sets were despatched, the remaining merchandise would have been left to the Knaptons and their associates to retail and distribute throughout the country. The Warburton edition would have been required reading for the literati of the latter half of the eighteenth century: Joseph Spence, Henry Fielding, Johnson and Boswell, Mrs. Piozzi, Horace Walpole, David Garrick, the Warton brothers, and Dr. Dodd, to name but a few likely and illustrious buyers. ${ }^{24}$ Judging by his critical dissection of Warburton's notes and commentaries in A Familiar Epistle to Mr. Warburton from Theophilus Cibber (1753), the son of Pope's most unglorified rival had a heavily annotated set. John Wilkes thought he could improve upon Warburton and began preparing an edition of his own: he had extra pages bound in with every volume of his 1751 set and compiled a considerable body of addenda. ${ }^{25}$ 
One illustrious non-buyer might be briefly noted. The royal patron to whom Pope presented one of Bounce's puppies (along with the immortal 'Kew' couplet) never glimpsed Warburton's edition. Unfortunately for Warburton, Frederick, Prince of Wales, died two months before the Pope edition was published. At least one literary celebrity baulked at the cost (boosted by unnecessary annotation) of the Warburton edition. Riding on the crest of the runaway Tristram Shandy, Laurence Sterne wrote his bookseller, Thomas Becket, from Paris asking him to send a shipment of books including 'All the Works of Pope --- the neatest \& cheapest edition --- (therefore I suppose not Warburtons) [sic] ${ }^{\prime}{ }^{26}$ When Sterne's library was put up for auction, one of the items listed was the 1754 Warburton edition of Pope's Works in ten volumes, valued at sixteen shillings. ${ }^{27}$ As the Shandean successor to Scriblerus, Sterne acquired the editorially stripped-down, hence least expensive and least Warburtonian of the first five posthumous editions.

The flood of Pope editions in the early 1750s is evident in the booksellers' production figures which are preserved in the Egerton collection. We can make a number of assumptions about how booksellers 'read' the market from these figures:

PRODUCTION OF POPE'S WORKS: The First Five Warburton Editions (1751-54) ${ }^{28}$

$\begin{array}{llrr}1751 a & \text { large } 8^{0} & 9 \text { vols } & 1500 \text { sets }=13,500 \text { single vols } \\ 1751 b & \text { crown } 8^{0} & 9 \text { vols } & 3000 \text { sets }=27,000 \text { single vols } \\ 1752 & \text { large } 8^{0} & 9 \text { vols } & 750 \text { sets }=6,750 \text { single vols } \\ 1753 & \text { crown } 8^{0} & 9 \text { vols } & 2500 \text { sets }=22,500 \text { single vols } \\ 1754 & \text { pot } 8^{0} & 10 \text { vols } & 3000 \text { sets }=30,000 \text { single vols } \\ & & \text { TOTAL } & 10,750 \text { sets }=99,750 \text { single vols }\end{array}$

We can assume that the booksellers reckoned sales of the cheaper editions (in crown and pot) would outnumber sales of the larger octavo editions of 1751 and 1752 by roughly four to one. The number of potential buyers of the more lavish large octavo edition was dwindling. Pope had implicitly foreseen this trend towards smaller formats in the 1729 Dunciad Variorum: 'Quarto's, Octavo's, shape the less'ning pyre, /And last, a little Ajax tips the spire' (I: 141-42). Sluggish sales of 1751a may have caused the booksellers to halve their order in 1752, although the availability of the cheaper crown edition - $1751 b$ - no doubt contribut- 
ed to the comparatively small printing of the 1752 Works. Many of Warburton's notes and commentaries were omitted from the cheaper editions (with his permission); such changes reduced the number of printed sheets and therefore helped keep costs down. The rise in production of the 1754 pot octavo - an even cheaper edition, but stretched out to ten volumes, again with Warburton's permission - suggests that sales were by no means declining.

However, these figures indicate production only and do not necessarily reveal when an edition sold out. The booksellers would have to anticipate demand and order accordingly from their printers, William Bowyer II for 1751a and William Strahan for at least some of the 1752 sheets. A faulty prediction could mean a long-term backlog in the stock-room or warehouse. The Knaptons and their associates would have felt fairly confident about the turnover of Pope's Works. If, for example, sales of the first small octavo - $1751 b$ - had been disappointing, then the Knaptons surely would not have ordered twenty-five hundred sets in the same format for the 1753 edition. The run of three thousand sets in 1754 suggests a healthy trend at the lower end of the market, especially with buyers who were not particular about the ornamentation of their book-shelves; so long as they had a text they might make do Pope's poetry without the bulk of Warburton's commentary. Even by today's standards, a total of over 10,000 nine- or ten-volume sets is staggering.

The lion's share of the Pope editions would have gone to the London market, most of them being sold at the Knapton shop in Ludgate Street near St. Paul's Churchyard and the other booksellers' premises. However, small consignments would have been shipped by coach to Oxford and Cambridge, York, Manchester, Bristol and Birmingham. We are not yet fully aware of how well distribution carried to more out-of-the-way places: that would depend on how actively provincial and Scottish booksellers dealt with their busier London counterparts. In Bath, the prominent bookseller James Leake had a reciprocal arrangement with the Knaptons, so that when a client such as Ralph Allen wanted such items as Montfaucon's Antiquities of France, the Dictionary of Commerce or another Pope edition, his order could be filled within a week. Allen, of course, helped speed things along with his improvement of the postal routes, so that correspondence between Bath and London often took the time of a return coach journey.

Assuming all sets eventually found a home, the booksellers seemed to be guaranteed substantial profits from the sale of Pope's Works. Yet there is a cautionary note: in 1755 the main proprietors, John and Paul Knapton, who had cleared a net profit of $£ 13134 \frac{1 / 2}{2}$. on their $25 \%$ 
share of the five Pope editions (Egerton 1959. f.30), verged on bankruptcy. Paul Knapton died, leaving his brother to put most of their stock and copyrights up for auction. Their share in Pope's Works seems to have been taken over privately by Andrew Millar whose name appears second in the list of booksellers on the 1756 imprint and heads half a dozen other later editions. This canny Scotsman who published Tom Jones, 'raised the price of literature' (according to Dr. Johnson) and earned Warburton's antipathy by publishing Bolingbroke's Works, evidently maintained a large share in Pope's poetic estate until 1766, after which Pope copyright was swallowed up by larger congers.

If anything, Warburton's ambivalent reputation may have helped boost sales and thereby sustain Pope's reputation throughout the second half of the eighteenth century. The number of posthumous editions attests to Pope's continuing influence throughout the latter half of the eighteenth century. More attention needs to be paid to the 'bestseller' side of Pope and how his works affected the minds of a new generation heading towards the Industrial Revolution. Not only Gibbon and Byron were inspired by Pope to varying heights of poetry and prose, but so too in countless different ways were the largely unknown buyers of Pope editions who propped up the book trade of their day.

We shall never be able to gauge completely the actual effect of all these editions on the reading of the following generations -- if this posthumous flood of editions in some way oversaturated the nineteenth-century public palate. But one effect is fairly certain: editing Pope enabled Warburton to die a rich, if frustrated, man. In his will Warburton left over $£ 20,000$-- far more than the poet who lent him fame. Warburton's editorial earnings estimated at $£ 26269 \mathrm{~d}$. from 1751 to 1754 (Egerton 1959. f.30), compounded with his bishopric, his inheritance from Ralph Allen and sensible annuities, were to be invested by his trustees. Eminent prelate yet unfulfilled editor to the end, Pope's literary executor left not a groat to literature.

DONALD W. NICHOL

Memorial University of Newfoundland 


\section{NOTES}

1. Jonathan Swift, The Complete Poems, ed. Pat Rogers (London: Penguin, 1983), p. 492

2. The satirical notion of an author's pages serving more pragmatic purposes than reading occurs throughout the century. Pope, following Garth's Dispensary, refers to pages which "scape the martyrdom of jakes and fire' and have been 'Redeem'd from tapers and defrauded pyes' (Twickenham V: 78, 80 and n.) In Christopher Smart's 1750 Horatian Canons of Friendship, written under the pseudonym of Ebenezer Pentweazle, a new mode of literary criticism is concocted on the basis of what authors' pages will line which trunks: 'As for your pastoral writers and epigrammatists, they (it would seem) ought only to line Trunks for little Misses, but your Epic writers, your Tragedians, and your Comedians might be a proper ornament for the Trunks of persons of Condition, and the works of the incomparable Mr. Justice Fielding might line the Trunk of an Emperor. As for the Rev. Mr. W---- [i.e. Warburton], Mr. R-----, Dr.-----, \&c.\&c.\&c. they should line the Trunks that are intended for exportation, for they will never be read in this kingdom, (vi-vii).'

3. The Correspondence of Alexander Pope, ed. George Sherburn, 5 vols. (Oxford, 1956), 4: 491 (Pope to Warburton, 2 January 1744). Pope's diminutive 'my things' and emphatic capitals on 'Great Edition' and Warburton's 'Notes' are worth noting: the attitude implicit in Pope's deferential remarks on the poet's relationship to the editor finds a pictorial correlative in the 1751 frontispiece (in which Warburton's centrally located image is brighter and more prominent than Pope's). Also in this letter, Pope warns Warburton of Colley Cibber's forthcoming Another Occasional Letter which will be the first of many attacks on Warburton as Pope's editor.

4. Terry Belanger, 'Booksellers' Trade Sales, 1718-1768', The Library, 5th series, XXX, 4 (December 1975), 281-302; 295-96.

5. Alexander Pope, Works, ed. William Warburton, 9 vols. (London, 1751) I, xii [the editor's 'Advertisement'].

6. British Library [hereafter BL]: Egerton 1959. ff. 29, 30.

7. Anon. To the Author of a Libel, entitled, A Letter to the Editor, Ec., (London: W. Webb, 1749), 1.

8. A Letter to the Editor and A Familiar Epistle to the Most Impudent Man Living, ed. Donald T. Siebert, Jr., Augustan Reprint Society, no. 192 (Los Angeles, 1978), pp. 22-23. Siebert identifies Bolingbroke as the author of the latter pamphlet (v-vi), although some passages have the malicious tone of Mallet's Scottish 'flyting' about them.

9. Thomas Edwards' popular Canons of Criticism evolved out of his Supplement to Mr. Warburton's Edition of Shakespear (1748); John Upton added an antiWarburtonian preface to the second edition of Critical Observations on Shakespeare (1748); Theophilus Cibber, son of Pope's Dunce laureate, parodied Warburton's ponderous style in A Serio-comic Apology appended to his revamping of Romeo and Juliet in 1748. 
10. For an account of Warburton's Shakespear in relation to Sir Thomas Hanmer's more lavish edition of 1744, see Harry Carter, A History of the Oxford University Press, vol. 1 (Oxford: OUP, 1975), 301-3. Hanmer's edition was Oxford's first publication in English; in 6 volumes, it sold for $£ 3$ by subscription in 1744 and fetched $£ 10$ in 1768 . His copy text was an annotated edition of Pope's Shakespeare.

11. Henry Fielding, Tom Jones (Harmondsworth: Penguin, 1981). References to Pope pop up at various intervals from the dedication and opening chapter on (pp. 36, 52, 241, 257, 340, 361, 532, 657). For the tribute to Warburton, see the invocation to Book XIII, p. 609.

12. Pope, Works (1751), 4: $169 n$. Ironically, this note was reworked from Warburton's preface to volume 4 of the 1748 edition of Samuel Richardson's Clarissa. When Richardson later decided to drop the preface, Warburton recycled it in the 1751 Pope footnotes, replacing Richardson's name with Fielding's, now crediting the author of Tom Jones with 'enriching ["Amatory" fiction] with the best part of the Comic art, [and Fielding] may be said to have brought it to its perfection.'

13. Pope, Works (1751), I: iii: 'I also give and bequeath to the said Mr. Warburton, the property of all such of my Works already printed as he hath written or shall write Commentaries or Notes upon, and which I have not otherwise disposed of or alienated; and as he shall publish WITHOUT FUTURE ALTERATIONS' [emphasis Warburton's]. Pope's will was published by Charles Corbett and (separately) by Weaver Bickerton in 1744. For the full text, see Maynard Mack, The Garden and The City (Toronto: U of Toronto Press, 1969), 263-65. Pope bequeathed 'all the manuscript and unprinted papers' to Bolingbroke; it would be difficult to imagine two more opposed literary executors.

14. R.H. Griffith, Alexander Pope: a bibliography, 2 vols. (Austin, 1922/27) 2: 524. The source for this unpublished letter is not given, although it was sent from Bedford Row on 23 May 1751.

15. The Correspondence of Horace Walpole, edited by Wilmarth S. Lewis et al (New Haven: Yale UP, 1937-83), 48 vols., 9: 116-17 (13 June 1751).

16. Pope, Works, ed. W. Elwin and W.J. Courthope, 10 vols. (London, 1872-89), III (1881) 534-35, for Warburton's cancelled opening page to 'Arbuthnot'. For the latter change, see D.W. Nichol, 'A Misplaced Plate in Warburton's Pope IV', Notes and Queries, vol. 30, no. 1 (Feb. 1983), 34-35.

17. Smith's $1751 b$ (i.e. the smaller crown octavo) set is unbroken: Edinburgh University Library (JA 1900-08).

18. Pat Rogers, Hacks and Dunces: Pope, Swift and Grub Street (London: Methuen, 1972; abridged 1980), 119-20.

19. Egerton 1954.f.19; see also Egerton 1952.f.4.: Warburton writes to Charles Yorke (8 August [1752]), 'I should have told you that George Arbuthnot is expected here but he is an easy good natured man, of no consequence to you or me, any further than his excessive love of red mullet'.

20. Egerton 1954.f.23 and f.29 (Warburton to Knapton, 13 August and 9 September 1751); BL: Add. MSS. $4312 . f .41$ (John Knapton to Thomas Birch, 1 October 1751). 
21. Egerton 1954.f.20 (Warburton to Knapton, 19 June 1751).

22. Letters of a Late Eminent Prelate, edited by Richard Hurd (Kidderminster, 1808), p. 104 (30 June 1753).

23. Letters of a Late Eminent Prelate, 105 (2 July 1753).

24. Sale Catalogues of Libraries of Eminent Persons, gen. ed. A.N.L. Munby, 12 vols. (London, 1971-75), records numerous owners of Warburton's Pope edition: Joseph Spence's set of the 1751 large octavo fetched $£ 2$ 10s. at auction; Spence also owned sets of the 1760 edition in vellum ( $£ 214 s$.$) , the 1764$ duodecimo in six volumes, the 1766 crown octavo in nine volumes, and the 1766 edition (vol. 5, p. 227; see also the introduction by Stephen Parks, p. 89). Fielding's set of the 1751 Works fetched $£ 2$ 2s. (vol. 7, p. 154). Mrs. Piozzi's twenty-volume set, including the Iliad and Odyssey, sold for $£ 7$ 7s. (vol. 5, p. 402). David Garrick owned both the 1751 and 1757 editions (vol. 12, p. 139). Hugh Blair owned an incomplete set of the 1759 edition (vol. 7, p. 205). Dr. Dodd had a nine-volume duodecimo edition (vol. 5, p. 377). No Warburton editions are listed for Goldsmith, Wordsworth, Browning or Lady Mary Wortley Montagu, although she kept her 1717 quarto edition of Pope's Works and a 1738 Essai sur l'homme (vol. 7, pp. 98, 71).

25. BL: G. 12850-58. John Butt refers to this set of $1751 a$ in Twickenham IV, ix, $307 n$. Wilkes' set of the 1751 Works is listed in two different auctions in Sale Catalogues of Libraries of Eminent Persons: on 3 May 1764 Wilkes apparently bid $£ 3$ 15s. for his own set (vol. 8, p. 99); and on 29 November 1802 it was purchased by Clarke for $£ 310$ s. (vol. 8, p. 165).

26. Letters of Laurence Sterne, ed. Lewis Perry Curtis (Oxford, 1935), 166 (12 [May] 1762).

27. Sale Catalogues of Libraries of Eminent Persons, vol. 5, p. 323. This set is listed as duodecimo (although it is presumably the pot octavo edition of 1754), 'with Cuts, fine Paper, neatly gilt'. Other Pope items in Sterne's collection included a cobbled set of works published between 1742-45, vols. 1, 2, 6, 7, 8, 9 (notably including the Memoirs of Scriblerus); a 1745 edition of An Essay on Man, bound together with Warburton's Commentary; the 1729 edition of The Dunciad in octavo; and the 1727 Pope-Swift Miscellanies.

28. This chart has been adapted from Egerton 1959.f.30. 